\title{
Ritual household deposits and the religious imaginaries of early medieval Dalmatia (Croatia)
}

Kelly Reed ${ }^{1}$

Oxford Martin School, University of Oxford, 34 Broad Street, Oxford, OX1 3BD, UK.

\begin{abstract}
This paper examines three early medieval ritual house deposits from Bribirska glavica, Dalmatia, Croatia. Discovered over the last century these items bring to the fore questions regarding the relationship between state and secular religion in a region that experienced numerous encounters and confrontations within and between different social groups. In particular, this paper explores these complexities using the term 'religious imaginaries' to describe how a sense of collective identity may manifest itself through individual and collective practice, focusing on the value of the discovered objects (chickens, eggs, whetstones and plant remains) and their ritual framings. In particular, the recovery of archaeobotanical remains highlights the importance of examining plant use in ritual deposits. Overall, despite some variation in the interpretations of the practice of 'special' offerings, the majority of studies draw the conclusion that items hidden in this manner provide a broadly protective or apotropaic function. Thus, these finds provide important insights into the development of religious and ritual beliefs in early medieval Dalmatia, suggesting that the community's religious imaginary comprised a set of values and symbols that hybridised the Christian faith with elements of 'folk magic' to re-inforce the apotropaic power of their ritual acts.
\end{abstract}

Keywords: Foundation deposit, Ritual, Chicken, Egg, Archaeobotany, Whetstone

\section{Introduction}

The complex themes of magic, religion, and ritual have long interested archaeologists and anthropologists and debate continues around the language and frameworks used and the manner in which to approach evidence of ritual activity. In the Oxford Dictionary ritual is described as "a religious or solemn ceremony consisting of a series of actions performed according to a prescribed order" (Stevenson 2010:1534). Yet, the nature of a ritual act is highly variable and scholars have presented a wide range of different descriptive terminologies and attributes to account for these different ritual activities through space and time (e.g. Brück 1999; Fogelin 2007; Insoll 2011; Manning 2014a; Osborne 2004; Rappaport 1999). Commonly, any deposit or item that was strange or inexplicable is referred to as religious, suggesting that religion consists of things with no perceived function or are just odd (Brück 1999; Fogelin 2007:59). Ritual deposits employed in an exchange with supernatural powers are also regularly termed a votive deposit, offering, dedication or dedicated object (see Osborne 2004 for discussion).

The concept of religious expression or customs that are distinct or set apart from 'official' religious doctrine and practices in medieval and post-Mediaeval discourse is usually described as folk religion, popular religion, or vernacular religion (e.g. Gazin-Schwartz 2001; Grau-Sologestoa 2018; Herva and Ylimaunu 2009; Hukantaival 2013). Often, the process of compartmentalising such activities in archaeological investigation has led to ritual behaviour,

\footnotetext{
${ }^{1}$ E-mail address: kellyreed@hotmail.co.uk
} 
with the exception of burials, in post-Roman contexts being either neglected or treated as a peripheral and exceptional aspect of human behaviour. This is particularly the case when dealing with Christianity, where anomalous finds that do not follow the perceived conformity or cohesion of the Christian religion are largely overlooked rather than discussed as an expression of supernatural or spiritual belief (Gilchrist 2008). Even the term superstition has negative connotations when used in medieval and post-medieval Europe, defined as "the worship of the true God by inappropriate and unacceptable means" (Gilchrist 2012:214). Nonetheless, 'magic' can be described as a form of ritual behaviour and therefore a part of religion (Versnel 1991).

Not surprisingly, the conversion of northern Europe to Christianity shows that the church generally tolerated and absorbed magical 'pagan' practices into new hybrid cultural forms that continued through 'official' medieval and post-medieval religion (e.g. Gilchrist 2008; Watkins 2004). Here we explore this phenomenon within the conceptual framework of hybridity. Hybridity has been used in anthropology, sociology and post-colonial theory to understand intercultural interactions, negotiation, and integration. Hybridity suggests that cultural integration occurs through a process of give-and-take to shape new identities with their own distinctive features, whereby neither group remained unchanged (Kraidy 2005). Recently, Thomas et al. (2017) suggested that hybridity offers the most powerful, flexible and nuanced framework for revealing the complex social mechanics of religious transformations of the early medieval period.

Ritual activities are therefore complex varying from individual to individual and from group to group and go beyond being either pagan or Christian. To encompass such thinking, this discussion will introduce the term 'religious imaginaries' as a language or concept to describe how a sense of collective identity may manifest. Deriving from the social sciences, the social imaginary is a set of values, symbols and common practice of a particular social group that derive from how people imagine their social existence, how they fit together with others and the social expectations that enable them to carry out collective practices (Dieleman 2012; Gaonkar 2002; Taylor 2004). Such imaginaries are not static, but are interwoven within the idea of how things usually go, how things should go and what would invalidate that practice both at the individual and group level. Thus, materialised religion and 'magic', in the form of amulets, relics, icons, clothes, sacred buildings etc., interact with people's imaginings and are used as meaning-making and world-shaping devices within their community (Dieleman 2012: 18). Inevitably then difficulties arise in accounting for and understanding the thoughts and beliefs behind these acts, especially as the boundaries between religion and magic, sacred and secular, ritual and routine are largely dependent upon the culturally subjective worldview and cosmology of a specific place and time (Barrett 1991:2).

Relational ontologies propose that all entities are subject to continuous development and change and what they 'are' is defined by their past and present relationships and interactions with other entities, where agency emerges when people engage with things (Herva 2009). Thus, for archaeologists the primary feature of identifying a ritual act and enabling us to draw a distinction between ritualised objects and their otherwise ordinary everyday function is context (Wait 1985:188; Osborne 2004). Barrett (1991:6) emphasises this by stating that the forms of knowledge associated with ritual or religious practices are derived from the same knowledge relating to everyday activities and thus intrinsically linked. Consequently, there was likely a continuum of practices from formal, ritualised events through to informal routine acts, such as everyday refuse discard, that existed outside of 'official' religion (Chadwick 2012:283). Ritual is then seen as an essential part of daily life, informing us about how past societies organised their world and the anxieties they faced (Insoll 2001, 2004; Thomas et al. 2017). 
The tradition of placing objects and symbols within, under, on, and around buildings for supernatural protection and good luck has been documented throughout the world and over the course of much of human history (e.g. Grau-Sologestoa 2018; Hukantaival 2007, 2016; Hamerow 2006; Manning 2014b). According to Hamerow (2006:1), special deposits recovered from within sealed or inaccessible areas of medieval buildings are remnants of a ritual act that was intended to protect it and its occupants. However, ancient and historical sources relating to house deposits are sporadic and so we must rely on archaeological interpretations, combining the material culture within its context of use. Yet, even archaeological studies have been somewhat limited in scope and rather disjointed in nature, with few overviews of the evidence for foundation deposits and whether they offer broader socio-cultural meaning, beyond identifying the prospect of 'superstition' or 'magic'. Moreover, discussions around the recovery of archaeobotanical remains from medieval 'ritual' contexts, beyond burials, seems largely non-existent from current literature. This paper therefore focuses on three household ritual deposits discovered from Bribirska glavica, Dalmatia, Croatia and explores whether these items can offer insight into the settlements religious imaginary. These deposits bring to the fore questions regarding the relationship between state and secular religion in a region that experienced many encounters and confrontations within and between different social groups and individuals. In particular, this paper will examine the value of the deposited objects (chickens, eggs, whetstones and plant remains) and their ritual framings. To put these finds into context, this paper will first briefly explore the socio-cultural and political environment within which these ritual activities manifested themselves.

\section{Dalmatia during the early Middle Ages $\left(9^{\text {th }}-12^{\text {th }}\right.$ century $)$}

Croatia is situated within a frontier region of early medieval western Europe and the Byzantine Empire. The early Middle Ages in particular is characterised as a complex period of intense rivalry among neighbouring powers, such as the Venetian Republic, the Franks (Carolinians), the waning Byzantine Empire and the newly formed Kingdom of Croatia (later in union with Hungary). As a result, the $7^{\text {th }}$ to $12^{\text {th }}$ century saw substantial upheaval, religiously, politically and socially, along with the mixing of different nations and cultures. Dalmatia's boundary also changed from the late Antique Roman province of Dalmatia, which encompassed the eastern Adriatic littoral and hinterland: modern day southern and central Croatia, a large part of present-day Bosnia and Herzegovina and a small part of Montenegro. To being integrated within the Duchy of Croatia during the $9^{\text {th }}$ century, which encompassed the coastal part of modern day Croatia and a large part of the mountainous hinterland. From AD 925-1102 the Kingdom of Croatia extended its territories across much of modern day Croatia, excluding Istria and much of southern Dalmatia, and a large section of Bosnia and Herzegovina.

Much of the discourse around Croatian origins and identity come from events of the $6^{\text {th }}-9^{\text {th }}$ century, however, much of the narrative seems largely constructed from later accounts and the political climate of the $19^{\text {th }}$ and $20^{\text {th }}$ century (Džino 2010). Typically this period was represented by historians as a time of Slavic incursions and mass migrations. This was largely supported by later sources such as the $10^{\text {th }}$ century treatise De Administrando Imperio ("On the Governance of the Empire"), which seems to have relied on oral sources and tells contradictory stories of the Croats arrival to Dalmatia (Džino 2014a; Majnarić 2018). More recent interpretations of the written and archaeological evidence suggest a process of change and transition in late Antique Dalmatia $\left(5^{\text {th }}-6^{\text {th }}\right.$ century), with the disappearance of the villa economy and the decentralisation of power and economy from coastal cities such as Salona, Narona and Epidaurus, as well as sporadic and localised episodes of military action (Džino 2018). Archaeologically their seems little consistent evidence of destruction from the 'Slavs' 
and the large number of fortifications are suggested by Džino (2014b) to emulate early and middle Byzantine fortified hill-top villages, and thus represent a redefined urban rather than military landscape. Džino (2017/2018) also suggests that the appearance of 'simpler' pottery types during later $7^{\text {th }}$ to early $8^{\text {th }}$ century, rather than being an indication of 'Slavic' invasion, is a manifestation of this social change, where economies moved away from large economic centres towards smaller community production.

Similarly, the appearance of row-grave cemeteries with grave assemblages and new funeral rites, such as cremation, is also seen as an indication of 'Slavic' invasion (Džino 2014b). However, evidence of burials between the $6^{\text {th }}$ and $9^{\text {th }}$ century are particularly complex in Dalmatia, with the additional, if infrequent, occurrence of cremation burials and inhumations covered in charred wood and ash (Džino 2010: 133; Petrinec 2015). Some have suggested these practices are a sign of 'Slav paganism', however, evidence of charcoal in graves has been noted in England and Merovingian Gaul for both practical and symbolic purposes (Džino 2010:134; Gilchrist 2008). As well as being evidence of burial feasts, Gilchrist (2008) suggests that in the late medieval period, the technique of lining the coffin with ash and hearth rakings may account for the belief that this would stop a troubled corpse's compulsion to return home and 'seek the warmth of the hearth'. Moreover, continuity in Christian late Antique Dalmatian burial traditions is seen through to the early Middle Ages (Džino 2010: 144, 2018; Vedriš 2015).

The picture which is therefore emerging suggests that small numbers of 'Slavic' groups probably moved in at the end of the $8^{\text {th }}$ century as a result of the Carolingian-Byzantine conflicts, which ended with the Treaty of Aachen in AD 812 (Ančić et al. 2018). This treaty left the eastern Adriatic towns to Byzantium, while their hinterland passed into the Carolingian sphere of influence (Majnarić 2018). Somewhere around AD 925 Croatia was elevated to the status of Kingdom when Duke Tomislav was crowned, although it probably took until the second half of the $11^{\text {th }}$ century to claw back many of the coastal cities of Dalmatia from Byzantium. Churches and monasteries became the focal architecture of this period, where the social elite could display their wealth and power (Vedriš 2015). Two major building periods are suggested: the first in the $9^{\text {th }}$ century was connected to the 'reChristianisation' of the Dalmatian hinterland and the restoration of late Antique churches, and the second to the 'Golden Age' of the Croatian kingdom in the $11^{\text {th }}$ century when new Benedictine monasteries were founded (Raukar 1999:192; Vedriš 2009, 2015). From the mid$9^{\text {th }}$ to the end of $11^{\text {th }}$ century grave goods were once again rare in Dalmatia and if present were limited to jewellery and metal dress accessories, some showing distinct Byzantine influences (Petrinec 2012). Accounts from the $10^{\text {th }}$ century also suggest a negative attitude from the Catholic Church towards the use of Slavic language in worship, although its use was eventually sanctioned in AD 1248 by Pope Innocent IV (Goldstein 1999:174; Vedriš 2015). The autonomous Kingdom of Croatia eventually came to an end in AD 1102, when a succession crisis led to the crown passing to King Coloman of Hungary, who was crowned "King of Hungary, Dalmatia and Croatia". 


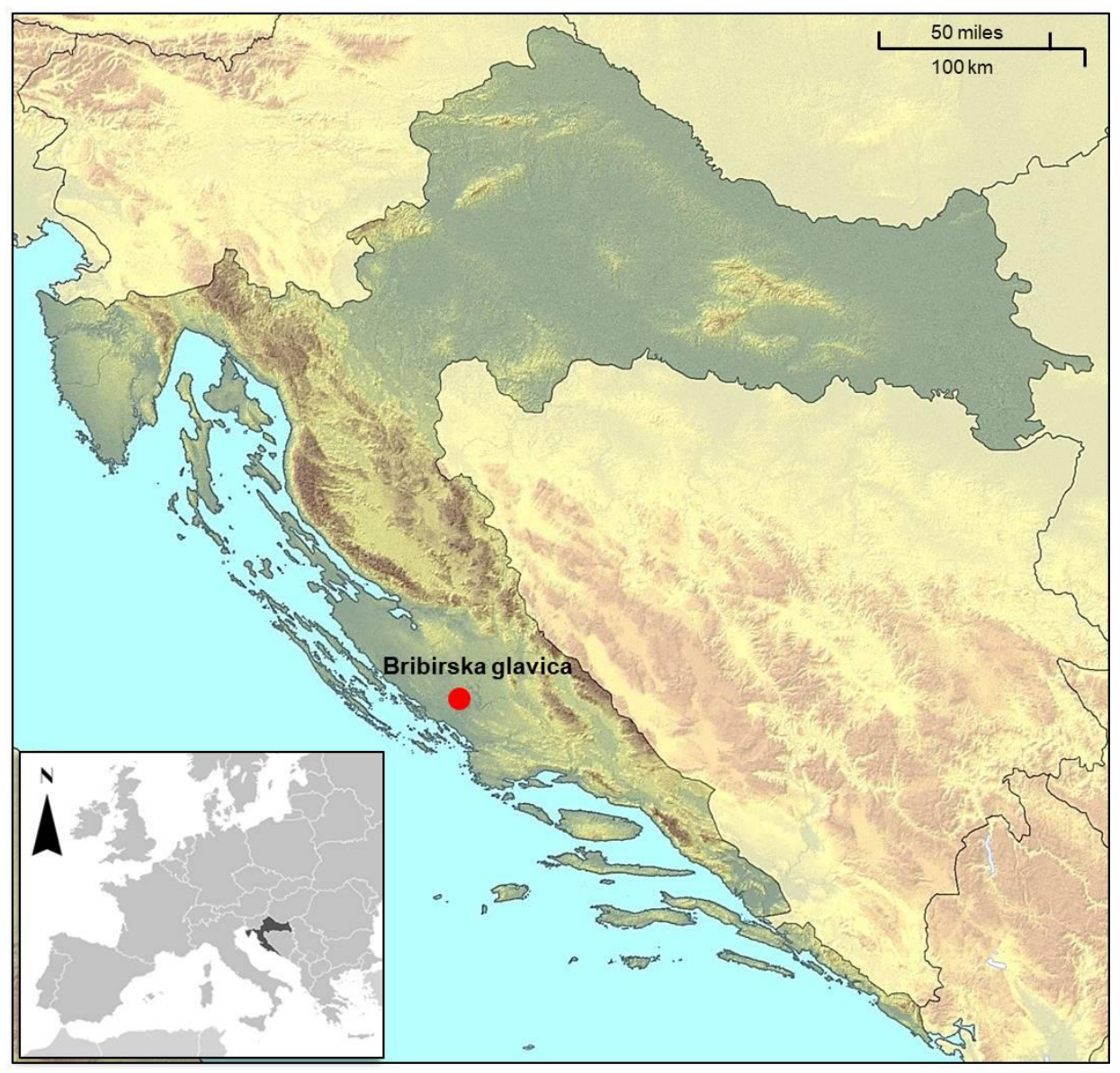

Fig. 1. Map showing the location of Bribirska glavica in Dalmatia, Croatia

\section{The Site: Bribirska Glavica}

Bribirska glavica is located in the Šibenik hinterland, about $12 \mathrm{~km}$ to the northwest of Skradin, in northern Dalmatia (Fig. 1). The site, located at the top of a $300 \mathrm{~m}$ high hill, has a long and complex history of occupation from prehistoric Liburni to ancient Varvaria and medieval Breberium. The site has therefore been of interest to Croatian archaeologists, being excavated with varying degrees of intensity, for over a century. Unfortunately, this has resulted in many of the finds being removed, archaeological contexts being disturbed and information lost, with many objects having no context or date, save for the fact they were found at Bribirska glavica (Milošević 2017). Parts of the site have also been restored or conserved over the years, including the outer walls and a number of the buildings.

Evidence of occupation at Bribirska glavica is sporadic, but excavations show continuity of settlement from the Roman period through to the Middle Ages. Three cemeteries are present, Groblje associated with the late Antique rotunda church dated from the $5^{\text {th }} / 6^{\text {th }}$ century (Ghica et al. 2017), Vratnice that is located next to the main entrance of the city, and Novi put located below the south-eastern wall, both dating from the $9^{\text {th }}$ century. In the later Middle Ages a one-naved church (possibly St John the Evangelist) is presumed to have been built after the rotunda church was abandoned (Džino pers. comm.) and became the seat of the Bribir archpresbyter (first mentioned by written records in AD 1229) (Smičiklas 1905: 316). Early medieval residences are also observed across the site, typically of a one-roomed rectangular shape. An early medieval fortified burg, a castrum, developed and soon gave its name to one of the eleven županijas, administrative units, of the Croat kingdom, B $\rho \varepsilon \beta \varepsilon ́ p \eta$ (Đermek 2015). During this time the site became the seat of a powerful and influential 
Croatian clan, the Šubići de Breberio. Paul I and his son Mladen II rose to power and governed Dalmatia, Slavonia, Chelm (Herzegovina) and Bosnia as viceroy (ban) for the King of Hungary from the 1270s until they lost favour in AD 1322 (Banovac 2018; Karbić 2005). Subsequent generations remained influential in Dalmatia until $14^{\text {th }}$ century.

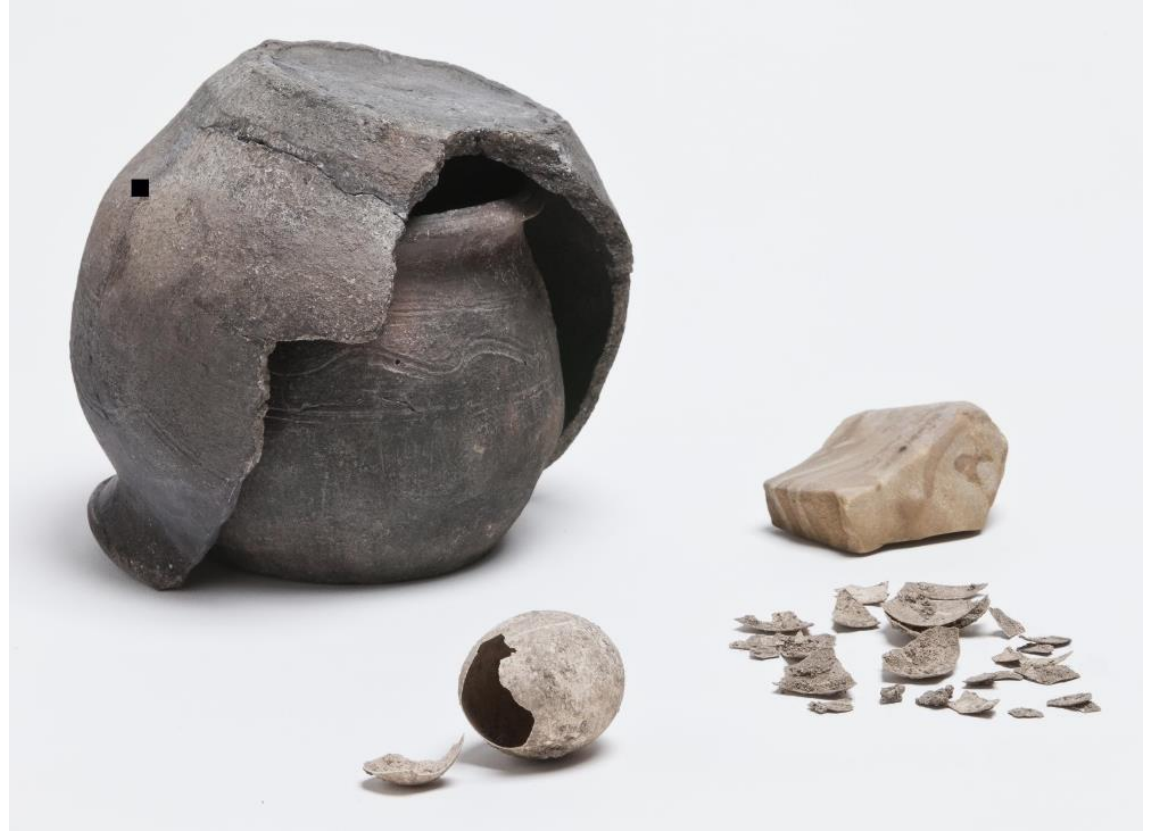

Fig. 2. The two pots and content from Bribirska glavica (Photo A. Z. Alajbeg).

\section{The finds}

From the last century of excavations at Bribirska glavica, a number of interesting finds have started to emerge. Most recently unpublished excavations directed by M. Zekan in 2012 revealed two clay pots (one covering the other) near the wall, and possibly under the hearth, of one of the early medieval houses on sub-locality Tjeme, close to the western city-walls. Reports of the find are patchy and the pots, still full of soil, were only discovered a few years later in a storeroom (Milošević 2015). Inside the pot was two eggs (one whole and one broken) and a whetstone made of sandstone (Fig. 2). Both pots are of a common fabric and design seen in the region from the $11^{\text {th }}$ to $13^{\text {th }}$ century and are suggested to have been contemporary, supporting the view that the pots were deposited together, one over the other (Milošević 2015:49). The larger pot is decorated with a double wave-line in the upper abdominal zone and measures $14.75 \mathrm{~cm}$ high, with a body circumference at the widest part of $16.5 \mathrm{~cm}$, an opening diameter of $13.6 \mathrm{~cm}$ and a bottom diameter of $9.5 \mathrm{~cm}$. The smaller pot also has a wave pattern but these are bounded by two parallel lines and measures $11 \mathrm{~cm}$ high, with a body circumference at the widest part of $12.2 \mathrm{~cm}$, an opening diameter of $11.9 \mathrm{~cm}$ and a bottom diameter of $9.7 \mathrm{~cm}$ (ibid.).

In 2016 the 0.51 soil sample from within the pot was wet sieved, through bucket flotation using a $250 \mu \mathrm{m}$ sieve, and the content examined for archaeobotanical remains (Table 1). Twenty seven identified plant remains were recovered, in particular, three barley grains (Hordeum vulgare) and nineteen seeds of cinquefoil (Potentilla sp.), along with about $2 \mathrm{ml}$ of small charcoal fragments. In 2018, one of the barley grains was C14 dated and returned a date range of cal AD 1116 - 1218 calibrated using IntCal13 (Conventional radiocarbon age 890 $+/-30 \mathrm{BP}$ at $95.4 \%$ confidence (Beta -495210$)$.

\begin{tabular}{|l|l|}
\hline Plant species & Number of plant \\
\hline
\end{tabular}




\begin{tabular}{|l|c|}
\hline & seeds \\
\hline Hordeum vulgare & 3 \\
\hline Galium aparine & 2 \\
\hline Gramineae (lrg) & 1 \\
\hline Gramineae (sml) & 1 \\
\hline Potentilla sp. & 19 \\
\hline Trifolium sp. & 1 \\
\hline Indet fragments & 15 \\
\hline
\end{tabular}

Table 1. The carbonised plant remains taken from the $12^{\text {th }}$ century pot, excavated in 2012 at Bribirska glavica

Two similar finds are also reported from the early Middle Age contexts at Bribirska glavica. The first was discovered in 1965, when a ceramic pot was excavated from the foundations of a house (Milošević. 2015). The second was reported in an excavation diary from July 12 , 1979 , stating that in square 250, an area close to the 2012 discovery, a pot was removed from the foundations of a wall and contained a number of bones, likely of chicken (ibid.). Field sketches exist and indicate that the finds were removed from a layer under the clay floor, however, no further analyses has occurred.

The only other finds of note at Bribirska glavica are the discovery of two coin hoards; the first, discovered around 1915, of around 18 coins of Venetian, Austrian and German origin wrapped in a piece of cloth, dating to the $12^{\text {th }}-14^{\text {th }}$ century (Mirnik 2007). The second, found in the 1960's, was of around 63 Venetian coins, one Anconitan and one Slavonian silverling, dating to the $12^{\text {th }}$ century, located on the southern side of St Mary's Church, next to its final buttress (Šeparović 2011). Other sites have coins deposited within building floors near Bribirska glavica, including, early Byzantine $\left(6^{\text {th }} / 7^{\text {th }}\right.$ century) coins under the northern wall of an early Christian Basilica in Šuplja Crkva, Solin (Gjurašin 2000, 86), a hoard of Ostrogothic coins $\left(5^{\text {th }} / 6^{\text {th }}\right.$ century) under the narthex, entrance or lobby area, of KlapaviceCrkvina church near Klis (Šeparović 2009) and beneath the wall of a Roman house in Škaljama, Bisk (Miloševic 2015). Coin hoards in themselves have occurred throughout history and are usually interpreted as being buried for safekeeping in times of uncertainty, with the intention to recover later (Curta 1996). Other interpretations suggest that coin hoards occurred as a result of inflation, when good coins are withdrawn and hoarded as a defence against repeated currency depreciation (Curta and Gândilâ 2011). Any number of coins may also be deliberately buried for ritual rather than economic intentions and this is seen from Roman and early medieval graves in Croatia (e.g. Mirnik 2005; Petrinec 2010: 203, 205). In Serbia to, Roman coins ( $2^{\text {nd }}$ to $4^{\text {th }}$ century) have been discovered in medieval female burials $\left(10^{\text {th }}\right.$ to $15^{\text {th }}$ century) where the coins were (re)used as ornaments on the costume of the deceased (Ćirić 2016).

\section{Exploring the role of special deposits}

The discovery of the three floor deposits at Bribirska glavica is relatively unique for the region. As far as we know, no other examples of early medieval house deposits exist in Dalmatia, although this may be due to these items not being recognised or published from $20^{\text {th }}$ century excavations. This next section explores the possible symbolism of the deposits discovered at Bribirska glavica through time and space, not to argue for continuity in practice, but rather to explore their ritual meaning and highlight how similar practices have adapted and changed depending on the religious imaginaries of the society within which it resides. 


\section{The role of the house in ritual activities}

Christian teachings provided little guidance for the practice of religion at home, moving formal devotion away from this private sphere to that of the church (Deane 2013). Domestic devotion was mostly characterised by prayer, reading (devotional books and books of hours), and the use of material objects in spiritual practice such as relics, rosaries, and portable altars (ibid.). Consequently, this left room for house-related rituals to continue or develop alongside 'official' practices. Thus, house-related deposits help us to explore associations between magic and ritual, the concepts of family, the household and daily domestic life. To explore the inhabitant's religious imaginaries foundation deposits must be understood against the broader context of how people related to their domestic space, instead of as an isolated ritual act. Some perceive the house as having a life of its own with a birth, life and death (Gerritsen 1999; Herva 2012). In particular, Herva (2010) argues, based on folk beliefs and relational thinking, that in $17^{\text {th }}$ century Sweden buildings acquired special properties from building deposits which in turn facilitated/maintained social relations between the building and people residing in it. As rituals around love and marriage, reproduction and childrearing, food preparation and consumption, and the prevention of illness are universal, it is plausible that these rituals could have been used in everyday structures (Gazin-Schwartz 2001:267). The construction of a house would then be closely linked with a ritual performance, where specific stages were required otherwise the 'power' of the house, and hence the health and fortune of the inhabitants, would be endangered.

In archaeology, rituals often focus on posts and foundations, as these represent the important structural component of the house, and in some societies special attention is given to the first post erected (e.g. Paulsson-Holmberg 1997; Reniere and Clercq 2018). Roman town planning involved a sequence of prescribed rites that culminated in a hole (mundus) being dug to receive a votive offering after which the surveyors could engage in setting out the orthogonal town grid (Woodward and Woodward 2004). The ancient author Sextus Placitus $\left(4^{\text {th }}-6^{\text {th }}\right.$ century CE, cited in Merrifield (1987:119)) also notes that land boundaries, wall foundations of houses and gates are ideal locations for votive deposits. Even in Exodus XII the blood of a sacrificial lamb was smeared on the doorposts of houses so that the plague would not smite the inhabitants (Hendel 2009). During the post-medieval period deliberate burials of pots in or under buildings (e.g. beneath thresholds or fireplaces) have been discovered in Germany and the Netherlands (Merrifield 1987:119-120).

In south Slavic folklore protective domestic spirits and malevolent demons of the field, forest and water are commonly described (Conrad 2001; Wenska 2015). For example, in Serbia and Croatia a protector snake, referred most commonly as čúvarica 'protector,' čúvarkuća 'house protector,' and kúćarica 'household one', was sometimes believed to live in the foundation wall near the threshold, or in, behind, or under the hearth (Conrad 2001). The "home fire demanded sacrifices to maintain the warmth of home and to improve the prosperity and health of its residents" (Wenska 2015:288). In Serbia, Vlahovic (1992: 153, cited in Wenska 2015) reports that to assure goodwill of spiritual beings a lamb or rooster was killed, the foundation was sprinkled with its blood, the head was immured and the meat eaten.

Ballads also preserve the ritual of foundation sacrifices. For example, the 'Legend of Rozafa' details the story of the building of Rozafa castle, Albania, where they recount the burying alive of a nursing mother in order to make the walls stay strong forever (Schott 2010:30-1). The need for a sacrifice during construction is also told in the Romanian ballad about the construction of the monastery in Arges, Wallachia and the Hungarian ballad about the construction of the fortress of Deva in Transylvania, Romania (Ivancu and Klimkowski 2016). In all three stories the women, who must be related to one of the builders, ensures the 
creation and meaning of the building by giving it her soul. These myths have also entered modern literature, such as the 1978 Albanian novel 'The Three-Arched Bridge' by Ismail Kadare (Ivancu and Klimkowski 2016).

\section{The ritual deposition of whetstones}

Whetstones were essential sharpening tools used from the Iron Age onwards and would have been an important part of a person's tool kit who used knives, axes, arrows, sickles, scythes etc. The type, shape and size of whetstones can vary, depending on things like the quality of the material and the uses for which it was made. Few studies explore these objects beyond their presence within site reports, with most of the research around whetstones coming from Scandinavia and northwest Europe where they are associated with trade, Viking myths and burials (e.g. Hansen 2009; Hukantaival 2016; Mitchell 1985; O’Connor 1991; Simpson 1979). In Viking burials the inclusion of whetstones has been interpreted as evidence of a social or symbolic statement or simply personal possessions of the deceased found along with other tools and utensils (Hansen 2009).

Old Norse literature and early medieval Germanic mythology depict whetstones as attributes of the gods, giants and kings, and has been linked with the thunderbolt of the old Germanic sky-god Tiwaz, indicating power and authority (Simpson 1979:100). The folklore surrounding thunder and their links with stone tools, such as adze and axes, are also noted throughout history, and especially in the Middle Ages, and their deposition may be associated with protecting the house and family against lightning strikes and other misfortunes (Carelli 1997; Johanson 2009; Merrifield 1987). Alternative accounts from the Roman period highlight the 'magical' powers of whetstones. For example, Pliny the Elder (N.H. 28.12,47) writes that when a poisoned man puts a whetstone that had been used to sharpen iron tools under his pillow, without his knowledge, he would be able to identify the poison and the time and place it was administered, but not the author of the crime (Saunders 2010: 33). Accounts from the $14^{\text {th }}$ to $19^{\text {th }}$ century link whetstones with lying, for example, in England the $18^{\text {th }}$ century saying 'to lie for the whetstone', was used to describe when a man who told the greatest lie in company is rewarded with a whetstone (Smith 2003). Late medieval punishment for lying and deception also included hanging a whetstone around the liar's neck (Winter 2012: 152).

Recently, the ritual deposition of whetstones in Gallo-Roman buildings has been noted in the northern part of Gallia Belgica in the lower river Scheldt valley (Reniere and Clercq 2018). Here whetstones, as well as other objects, were seen to be deliberately buried in a specific structural component of the timber-framed stable houses. They argue that "the deposit of these stones was a cultural practice (De Clercq 2009); a ritual act performed by local communities, connecting the life cycle of the family to that of the house and to the seasonal rhythm of harvest, of which whetstones were an essential part" (Reniere and Clercq 2018: 67 ). Thus, they suggest that the local phenomena, confined to the late $1^{\text {st }}-2^{\text {nd }}$ century $A D$, symbolises a cultural adaptation of a widespread ritualisation of fertility and protection that merged Roman and local gods. Other objects were also discovered in foundation deposits in this region, including fragments of quern stones, complete or deliberately broken pots and loom weights (Reniere and Clercq 2018). In Knesselare Flabbaert, at one side of the house entrance, a whetstone associated with a complete pot was found (De Clercq, 2009:334). Here they suggest that whetstones are closely linked to harvest and fertility, as whetstones are important for sharpening scythes and sickles, and may symbolise a successful harvest and hence prosperity and the continuation of a fruitful household (De Clercq, 2009:336).

In Croatia, the early medieval site of Orlić yielded about 15 whetstones from the mounds above the graves and pits and in pit I along with a fragment of a millstone (Petrinec 2015). 
Generally though finds of whetstones are rare and occur only in some 'pagan' type graves from ca. 8th-early 9th century, i.e. burials with grave goods (or furnished burials), such as at Nin-Materize, Nin-Ždrijac, Kašić-Maklinovo brdo, Kašić-Razbojine and Velim Velištak (ibid.).

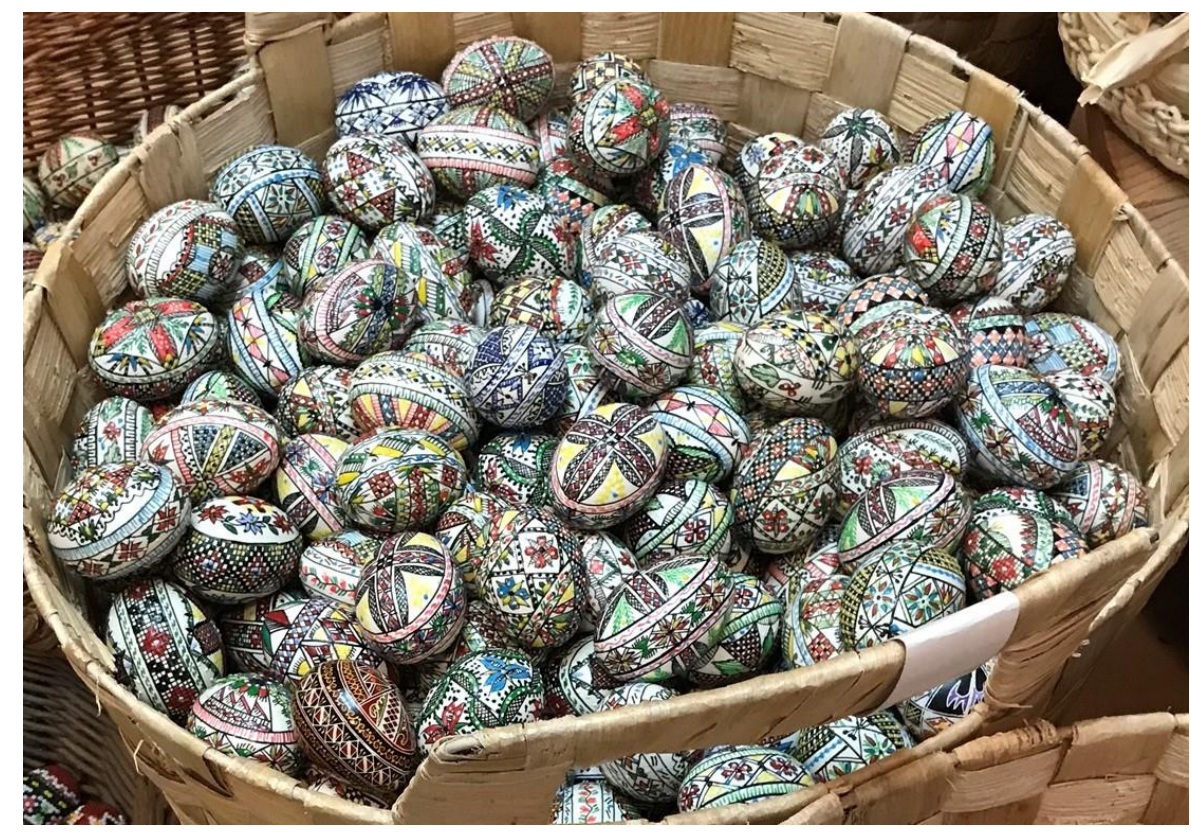

Fig. 3. Decorated Easter eggs from a local shop in Bucharest, Romania

\section{All life comes from an egg (Omne vivum ex ovo)}

Eggs have been commonly associated with symbols and myths throughout time. The egg can both nourish as food as well as give birth to a new generation and has been symbolic of creation and resurrection. Even today eggs are an integral part of Easter celebrations, likely borrowed from 'pagan' rituals, to be symbolic of the resurrection of Christ. Eggs have been linked with creation myths in Egyptian, Greek and Roman mythology and ritual practices (e.g. Alsobrook 2008; Papy 2000; Sheppard 1958). The Romans believed eggs held aphrodisiac and curative powers (Pliny N.H. 29, 48; N.H. 29, 11, 46-51), were symbolic of fertility and of life after death. Eggs representing food and/or symbolic meaning have therefore been found in Roman burials and tombs (e.g. Spinosa 2014:20). The concept of a cosmic egg resurfaces in medieval Europe and has been associated with eggs, particularly Ostrich eggs, suspended in churches during this and the Renaissance period (Alcock 2007: 22; Green 2006; Newall 1968). Easter eggs and egg decorating are attested from the $15^{\text {th }}$ century in Europe and since then eggs have played a part of various varied folk traditions (Fig. 3). In Bulgaria the crumbs from the Christmas meal are gathered and guarded until harvest time when they are thrown along with a cauldron of water and an egg under the first cart for good luck (Slaveykov 2014). In Greek Macedonia, peasants used to bury red Easter eggs in their vineyards, as well as used as a charm against hail, to cure cattle and the first red egg made was used to bless a child in the household (Newall 1968). In parts of Russia, eggs were also included as an important part of burial rites (ibid.). Thus, even in recent times the egg was an emblem of increase, a life preserving charm, a sacrificial object and even a pattern of the Eucharist (Newall 1968).

Archaeological evidence of ritual egg deposits is sporadic and few studies explore regional patterns. Most common are the recovery of eggshells in burials. In Kukruse, Estonia, two richly furnished female burials dated to the $12^{\text {th }}$ - early $13^{\text {th }}$ century each contained an egg 
(Jonuks et al. 2018). Small specks of colour indicated that one of the eggs was painted and has been linked to Christianity, the resurrection and the eternity of the soul. This tradition was seen up to the 1920's in parts of Poland, Macedonia and Thrace where painted eggs are laid on graves (Newall 1968: 272). The other unpainted egg from Kukruse was located by the feet of the deceased with other grave goods and was interpreted as a food deposit linked to non-Christian burial practices (Jonuks et al. 2018). Eggshells also occur quite often at $10^{\text {th }}-$ $13^{\text {th }}$ century cemeteries in the lower reaches of River Daugava, Latvia and have been associated with the spread of Christianity in the region (ibid.).

One interesting site, Sardis, Turkey, uncovered two nearly identical ritual offerings buried beneath the floor of a $1^{\text {st }}$ century AD house or workshop (Bruce and Raubolt 2015:449). Each deposit contained a coin, a bronze needle and pin, an iron stylus point or pin, and a whole egg, one of which was preserved intact and pierced on one side and sealed between two pots (Fig. 4). Similar deposits were found at Sardis in 1913, in the Artemis temple area, were more than a dozen ovoid cups were recovered at the base of walls, usually outside of buildings, with each containing a coin, the shell of an egg and a small bronze instrument (Bruce and Raubolt 2015:450). At the ancient city of Lattara, France, a foundation offering in a storehouse, dated to around AD 25-60, yielded pottery vessels, oil lamps, a coin, a pin (made out of bone), an egg and several plant products (Rovira and Chabal 2008). Eggs have also been found deposited, along with other items, in a number of medieval villages and churches across Hungary (Daróczi-Szabó 2010), as well as in post-medieval buildings in Grossweitzschen, Saxony, Badonviller, France and London, UK (Newall 1968). Interestingly Newell (1968) also highlights a popular legend from Scallow Castle, Shetlands, where it was told that in AD 1600 the mortar was blended with a mixture of eggs and blood, and likely symbolised a sacrificial rite. The egg could therefore be a substitute for human life and representative of the human/blood sacrifice required to be included in the foundations of new buildings (Newall 1968: 261). In Slavic folklore eggs were used for casting spells, were typical sacrificial offerings for various forest spirits and were buried at the feet of the deceased during funerary rituals (Uspieński 1985, 146, cited in Wenska 2015).

Interestingly, eggshells were also recovered from two late medieval graves at Bribirska glavica (Milošević 2015) and this pattern continues across Dalmatia. For example, in Glavičine, near Split, a $9^{\text {th }}-10^{\text {th }}$ century necropolis consisted of 130 graves and a large number contained grave goods including earrings, rings, copper plates and the shells of eggs (Markotić 1964). At the site of Orlić, one of the pits associated with a burial, possibly dating to the $8^{\text {th }}-9^{\text {th }}$ century, contained eggshells (Petrinec 2015). Eggshells were also found in medieval graves at Gajine in Kaštel Sućurac, Glavičine in Solin, Stombrate in Bijaćci, Dubravice near Skradin, Borinovce in Trilj and Putalj in Kaštel Sućurac (Petrinec 2015; Milošević 2015). Even in eastern Croatia, animal bones, pottery and eggshells were identified, along with other items, within late Avar (AD 710-810) graves (Papeša et al. 2015). 


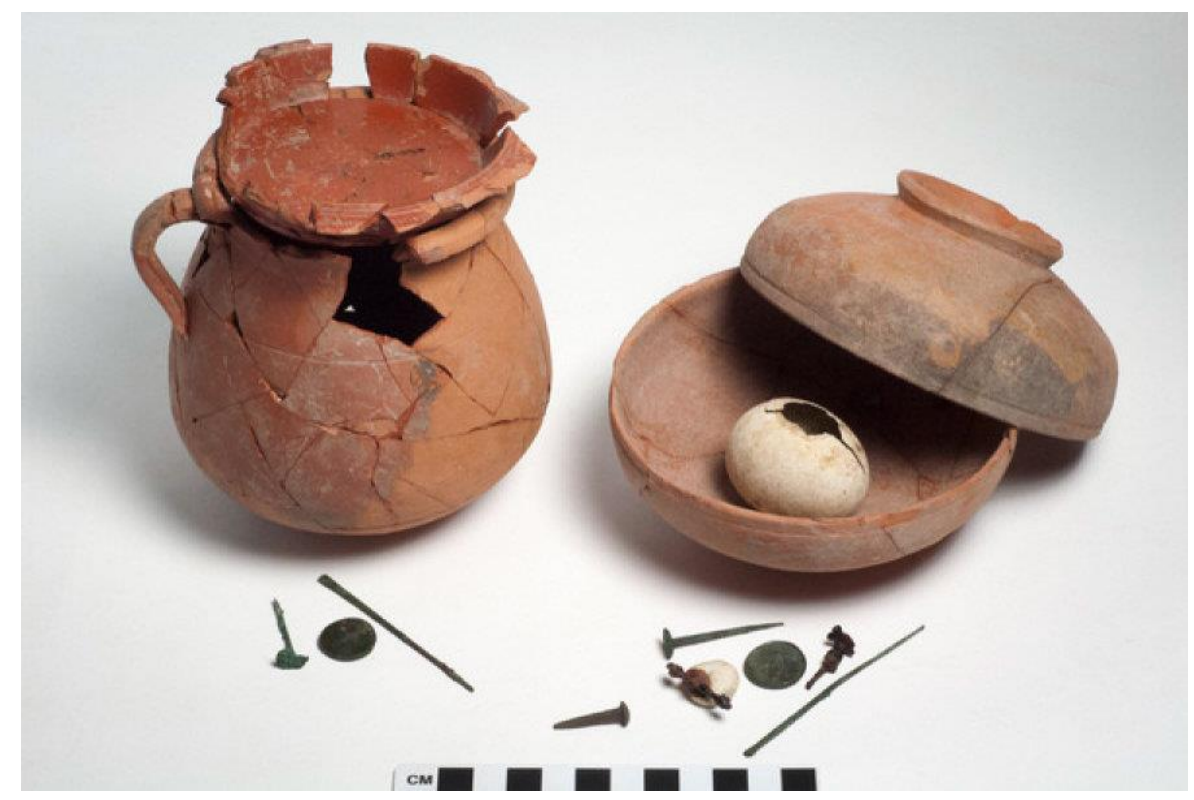

Fig. 4. A ritual deposit, found intact beneath a first century Roman house in Sardis, Turkey (Photo Archaeological Exploration of Sardis/Harvard University).

\section{Chicken symbolism}

The use of animal bones in ritual contexts dates back to prehistoric times, but the domestic fowl, or chicken, did not appear regularly in Europe until the $1^{\text {st }}$ millennium BC (Sykes 2012). It increased in popularity around AD 1000 across Europe due most likely to an increase in urbanisation and the Christian edicts that enforced fasting and the exclusion of four legged animals from the menu (Loog et al. 2017). As well as providing eggs and meat for food, chickens have also been associated with a range of religious and ritual practices since their establishment in Europe and are regularly seen mixed into religious and nonreligious images (Feider 2017). In Roman society there were 'sacred chickens' used for portents, they were associated with the cult of Mithras and the god Mercury, and are commonly found in late Roman burials (e.g. Cooke 1998: 231; Feider 2017; King 2005; Martens 2004). Local variations in the association of chickens with other Roman deities in Britain and Gaul are also seen and are suggested to be linked with symbols of abundance and prosperity (Feider 2017: 355). The cock stone or Alectorius was a good luck charm retrieved from the gizzard of a cock or capon and was used at various points in history for either slaking thirst, conferring invincibility, promoting desirable personal qualities or for treating a range of conditions (Duffin 2007). In the medieval period chickens seem to have a multisymbolic nature symbolising vigilance and protection, an association with priests' sermons and the cockerels crow, as well as representing foolish, lusty and aggressive creatures that were incorporated in non-religious tales (Feider 2017: 350). In $19^{\text {th }}$ century Slavic folklore, chickens were used in ceremonies to 'tame' the domestic demon, usually cooked and eaten as part of a ritual feast (Wenska 2015). Further, Uspieński (1985: 226, cited in Wenska 2015) mentions that in Russia slaughtering a chicken often accompanied moving into a new house or laying the foundations.

In the Basque Country, northern Iberian Peninsula, five building foundation deposits, dated to the $12^{\text {th }}-13^{\text {th }}$ century, were identified consisting of inverted pots containing the remains of chickens (Grau-Sologestoa 2018). Here the deposits were interpreted in the framework of folk religion practices that coexisted with the official religion, playing complimentary roles in the construction of socio-political communities (ibid.). Numerous medieval sites in Hungary have also yielded sacrificial animals in pots (Daróczi-Szabó 2010). In particular, Kána, 
Hungary, had 21 inverted pots buried in houses, pits and ditches dated to the $12^{\text {th }}-13^{\text {th }}$ century (Daróczi-Szabó 2014). Fifteen contained sacrificed animals including chickens, dogs, cats and fish, and they were typically found with a metal object, mostly nails and it is suggested that this was due to irons protective role (ibid.).

In Croatia, chickens are usually associated with burials, for example at Orlić evidence of chickens have been found within pits associated with burial mounds, along with ash and ceramic fragment (Petrinec 2015). In particular, one pot was filled with ash and the bones of a possible chicken, one pit had a whole chicken skeleton, and Grave 2 also contained a possible chicken located next to a pot (ibid.). Chicken bones are also noted in other early Middle Age grave contexts in the region e.g possibly at Borinovce in Trilj, Croatia, where bird bones were identified along with an egg, and at Grborezi, near Livno, Bosnia and Hercegovina (Milošević 2015; Sokol 2015:82). From the second half of the $9^{\text {th }}$ century, one female burial mound at Bojná, western Slovakia, contained grave goods that included a vessel filled with bird bones (Pieta and Robak 2012). These unique burials have been linked with 'Slav' customs that included funerary feasts and food offerings for the dead.

\section{Plant remains in ritual deposits}

Typically 'ritual' deposits focus on animal bones and artefacts and archaeobotanical analyses is rarely undertaken in archaeological excavations and few studies examine these remains within their wider context (Lodwick 2015). This is particularly seen for the medieval period in Croatia (Reed 2016) and southeast Europe generally, where few archaeobotanical studies have occurred. However, difficulties exist when linking plant remains with specific human activities, as a range of formation or taphonomic processes can occur (Van der Veen 2007). At Bribirska glavica, the plant remains are carbonised, which means that they had to have come in contact with fire. This alone conjures up a range of questions, for example, were the grains or plant parts burnt deliberately as part of a 'ritual' activity, were they collected and deposited within the pot or were they the remains of a meal that had been purposefully burnt? The dating of one barley grain to the $12^{\text {th }}$ century may support its link to the pots which where dated to the $11^{\text {th }}-13^{\text {th }}$ century. However, this only proves that the barley grain was relatively contemporary with the ritual deposit. Unfortunately further dating was not possible, but if conducted could have confirmed whether the whole plant assemblage dates to the same period. Alternatively, as the pot was found near a hearth, the plant remains could simply represent seeds/plants discarded with no 'ritual' connotations. The plants could have been accidentally incorporated within the soil near the pot and as the soil filled the void after burial, the plant remains became accidentally trapped inside (See Pelling at al. 2015 for a discussion on the intrusion of archaeobotanical remains).

The use of plants in ritual activities is widely recorded in the Roman period and has been identified from a number of burials and shrines across the Empire (e.g. Reed at al. 2019). Burial rites involving the deposition of objects and food in graves was a common phenomenon in many regions of Europe in the late Antique and early Middle Ages. In eastcentral Sweden, two early medieval cremation burial mounds (AD 600-800) contained remains of cereals, collected berries, nuts, root and stem tubers as well as ruderals, field weeds and meadow plants burnt on the funeral pyre (Hansson 2005). In England, a $7^{\text {th }}$ century Saxon barrow at Ford contained the skeleton of a male individual equipped with a hanging bowl containing onions and crab-apples, seax, a shield with sugar-loaf boss, two spears, a buckle, and a bone comb (Musty 1969).

From the ancient Roman sources too, cereals, pulses, fruits, cake, garlands of flowers etc. have all been noted as appropriate offerings for the gods (Robinson 2002; Ovid, Fasti, I). In particular, Ovid (Fasti, VI) describes how the farmers used to parch wheat in their ovens for 
the oven goddess. The most analogous find to Bribirska glavica is the foundation offering at the Roman port of Lattara, France, AD 25-60, which consisted of pottery vessels, oil lamps, a coin, a pin (made out of bone), an egg and several plant products (Rovira and Chabal 2008). The plant remains consisted of cereals (including barley), pulses and fruits and were interpreted as being burnt, along with other wooden items, as part of an offering to the domestic gods (e.g. Lares or Penates) for protection and success for their business (ibid.).

Medieval healing revolved around the belief that plants, animals and other objects would ease or cure an ailment (e.g. Arsdall 2002; Watson and Gilchrist in press). In the pot from Bribirska glavica, cinquefoil (Potentilla sp.) was recovered and this plant has been found in various medical manuscripts (e.g. Arsdall 2002:145). Moreover, Potentilla reptans has even been proved to contain moderate antimicrobial activity that could have helped treat wounds and bacterial infections (Watkins et al. 2012). Prescriptions against the 'sweat' and the plague in an English $15^{\text {th }}$ century remedy book includes a recipe where the juice of potentilla is mixed with vinegar, water and sugar and drunk lukewarm (Connolly 2016). However, as medical manuscripts were usually prepared by monks it's unclear how much of these treatments and compilations would have filtered out to the laity. Cinquefoils five leaf symbol was also used in medieval architecture (Fig. 5) as an emblem on medieval knight's shields and, according to legend, as protection against witches (Kynes 2017). Other stories suggest their leaves if hung over a door would provide protection, while the flower and leaves could make a charm to strengthen the relationship between mother and child. Even today plant magic includes a large range of species including cinquefoil for protection and strength (ibid.).

Certain plants, woods and resins when burnt can also release fragrant smoke and has been noted in early Christian and 'pagan' contexts. It was particularly common, along with libations, during the Roman period, being a cheap way to offer sacrifice (Caseau 2007). Early Christianity soon considered incense offering as a symbol for idolatry, as God, as a spiritual being, "did not need or relish material offerings" (ibid: 75). Yet, the cultural association between sacred space, sacrifice and incense, resulted in the eventual adoption within Christian practices by the late Antique period (Lents 2016).

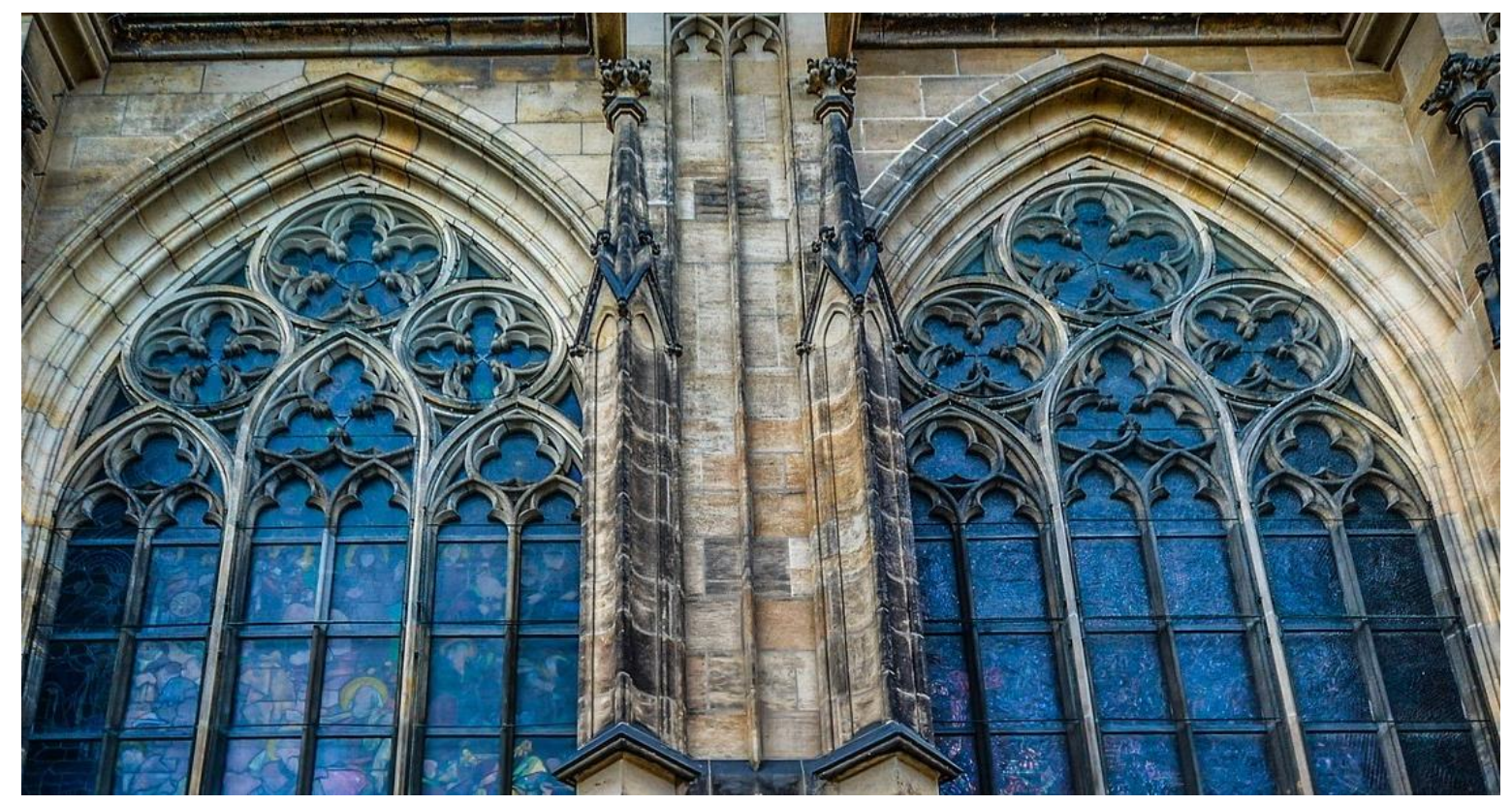

Fig. 5. Example of Gothic tracery in a British medieval Church window; the Cinquefoil (5 leaf), Quartrefoil (4 leaf) and Trefoil (3 leaf). 


\section{Conclusion}

The study of ritual activities is of value to our understanding of the past, not just because it sheds light on the beliefs and worldviews of those who performed or participated in them, along with their attitudes towards their homes and the surrounding landscapes, but because it furthers our understanding of the complex relationship between people and objects. Despite some variation in the interpretations of the practice of house deposits or offerings, the majority of studies draw the conclusion that items hidden in this manner provide a broadly protective or apotropaic function. Further, any object can be 'converted' and function as a ritual item, regardless of any functional properties it may possess, if it is perceived as such within the appropriate context. This paper has only touched on the wide range of symbolism and meaning associated with these objects and this diversity highlights the danger in over interpreting an artefact and that any meaning ascribed should be examined within its wider context.

The term hybridity is a way of viewing culture and human action and, in this context, suggests that religious action is not a discrete entity but is continuously transforming and recombining. Religious imaginary is also a helpful term to encompass how the collective identity of a group manifests itself from the way people view themselves and each other, merging and re-forming social norms as to what is acceptable and unacceptable behaviour. At Bribirska glavica, Croatia, the three early medieval (c. $12^{\text {th }}$ century) house deposits clearly represent some form of deliberate ritual activity. The act of depositing apotropaic objects within building foundations, whether before or after the building was completed, was probably an important element of a 'ritual' event created for the benefit of the family inhabiting the house and was presumably intended to function in perpetuity. The find of the egg and whetstone together could be aimed at reinforcing the apotropaic power of the sacrifice or protection. However, from the evidence presented the objects rather than simply being a symbol of apotropaic magic could have served multiple purposes with numerous meanings. For example, the egg could be a food item, a representation of human sacrifice, a symbol of fertility, as well as linked to Christianity and the resurrection. The possible inclusion of plant remains within the deposit could have signified an additional element within the 'ceremonial' act e.g. the burning of plants for incense or for other symbolic reasons. The questionable association of the plant remains within the 2012 pot prevents any assumptions about the types of symbolism that plant remains may have contributed at this site. However, it is clear that this area is completely ignored in research around medieval rituals and magic and warrants examination.

We may conclude that the objects in the pots were constructed in different ways within the context they were deposited, by different individuals, to reflect their religious imaginaries. In particular, these floor deposits suggest that shared 'folk' beliefs had a valued place in the pervading Christian society, emerging from the hybridisation of individuals religious and social imaginaries, making common, if unsanctioned, practice possible. This is particularly interesting within the social context of medieval religious persecution (e.g. Bradley 2010; Hutton 2016). Even in Dalmatia, the city-statutes of Split (AD 1312), Trogir (AD 1322), Skradin (AD 1350), and Sibenik (AD 1379) state that a practitioner of magic or herbalist art (artes magicales bel herbariae) would be condemned to burn at the stake (Petaros et al. 2013). The discovery of these objects in such a climate highlights again the complexity of religious/ritual expression. If this was a shared 'acceptable' practice at Bribirska glavica then instead of separating Christian from Pagan, breaking the narrative into fragments, we should study these finds as an organic whole in order to get some sense of the objects function and how it was understood by members of the community (Watkins 2007). In this sense, a 
chicken could still symbolise a desire for wealth, fertility, protection or devotion without an explicit connection to a particular religion or cultural group.

The emergence of this tradition at Bribirska glavica in the $12^{\text {th }}$ century may also suggest that socio-economic and/or political changes occurred, resulting in the incorporation of existing practices into new rites, where the focus shifts to other objects and places i.e. objects in pots placed in house floors. It is unclear what specific event or series of events may have occurred at the settlement to trigger such changes in religious expression, although regionally changes have been noted. For example, a series of new Benedictine monasteries were founded during the $11^{\text {th }}$ century (Raukar 1999:192; Vedriš 2009, 2015) and most importantly the rule of the Trpimirović dynasty came to an end at AD 1091. At this point the realm was thrown into a succession crisis and conflict ensued until the crown passed to the Árpád dynasty with the coronation of King Coloman of Hungary as 'King of Croatia and Dalmatia' in Biograd in AD 1102. This upheaval may have had a profound effect on the community's sense of security and stability and may have resulted in the resurrection or creation of hybrid forms of religious expression to protect the household. Unfortunately, the lack of detailed comparative studies for the post-Roman period within southeast Europe means it is difficult to determine how religious imaginaries altered to incorporate these different ways of expressing religious/ritual beliefs. Further research is clearly needed to (re)identify and examine these types of deposits in order to understand the similarities and differences between the religious imaginaries of early medieval societies and their connections with the socio-political environment.

\section{Acknowledgement}

Many thanks to Daniel Džino for his comments and helpful suggestions on previous drafts of this paper, to Nathan Clay and Alexandra Sexton for introducing me to the world of social imaginaries and to Gemma Watson for providing helpful references. A special thanks Ante Milošević, Nikolina Uroda and the Split Museum for funding the C14 date of the barley grain from the pot discovered at Bribirska glavica.

\section{References}

Alcock J.P. 2007. The Egg: its symbolisim and mythology. In: R. Hosking (ed). Eggs in Cookery: Proceedings of the Oxford Symposium of Food and Cookery 2006. Devon: Prospect Books, pp. 20-29.

Alsobrook K. 2008. The Beginning of Time: Vedic and Orphic Theogonies and Poetics. Unpublished MA thesis, Florida State University.

Ančić M., Shepard J., Vedriš T. 2018. Imperial Spheres and the Adriatic: Byzantium, the Carolingians and the Treaty of Aachen (812). London: Routledge.

Arsdall A.V. 2002. medieval Herbal Remedies: The Old English Herbarium and AngloSaxon Medicine. Routledge, London.

Banovac I. 2018. Komunalna društva u Dalmaciji i Šubići za vladavine Pavla I. Šubića (Communes in Dalmatia and Šubić dynasty during the rule of Paul I. Šubić). Unpublished thesis, University of Split

Barrett J.C. 1991. Towards an archaeology of ritual. In: P. Garwood., D. Jennings., R. Skeates and J. Thomas (eds). Sacred and Profane. Oxford: Oxford University Committee for Archaeology Monograph 32, pp. 1-9.

Bradley C.M. 2010. Defining Ancient Magic: A Brief Historiography and Exploration. EX POST FACTO: Journal of the History Students at San Francisco State University 19: 149164. 
Bruce W., Raubolt E.D. 2015. Sardis, Ritual Egg Deposit (Turkey). In: K.B. Metheny and M.C. Beaudry (eds). Archaeology of Food: An Encyclopedia. London: Rowman \& Littlefield, pp. 449-50.

Brück J. 1999. Ritual and rationality: some problems of interpretation in European archaeology. European Journal of Archaeology 2(3): 313-344.

Carelli P. 1997. Thunder and Lightning, Magical Miracles. On the Popular Myth of Thunderbolts and the Presence of Stone Age Artefacts in medieval Deposits. In: H. Andersson., P. Carelli and L. Ersgård (eds). Visions of the Past. Trends and Traditions in Swedish medieval Archaeology. Lund Studies in medieval Archaeology 19. Stockholm: Riksantikvarieämbetet Arkeologiska undersökningar Skrifter 24, pp. 393-417.

Caseau B. 2007. Incense and Fragrances from House to Church. In: M. Grünbart., E. Kislinger., A. Muthesius and D. Stathakopoulos (eds). Material Culture and Well-Being in Byzantium (400-1453). Vienne: Verlages der Österreichischen Akademie der Wissenschaften, pp. 75-92.

Chadwick A.M. 2012. Routine magic, mundane ritual: towards a unified notion of depositional practice. Oxford Journal of Archaeology 31: 283-315.

Ćirić G. 2016. Rimski novčići u ženskim srednjovekovnim grobovima sa teritorije Srbije: mogućnosti interpretacije, Etnoantropološki problemi 11(3):731-747.

Connolly M. 2016. Evidence for the Continued Use of medieval Medical Prescriptions in the Sixteenth Century: A Fifteenth-Century Remedy Book and its Later Owner. Medical History 60(2): 133-154.

Conrad J.L. 2001. Male mythological beings among the South Slavs. SEEFA 6(1): 3-9.

Cooke N. 1998. The definition and interpretation of Late Roman burial rites in the Western Empire. Unpublished PhD thesis, University College London.

Curta F. 1996. Invasion or Inflation? Sixth- to Seventh-Century Byzantine Coin Hoards in Eastern and Southeastern Europe. Annali dell'Istituto Italiano di Numismatica 43: 181-202.

Curta F., Gândilă A. 2011. Hoards and Hoarding Patterns in the Early Byzantine Balkans. Dumbarton Oaks Papers 65/66 (2011-2012): 45-111.

Daróczi-Szabó M. 2010. Pets in pots: superstitious belief in a medieval Christian $\left(12^{\text {th }} 14^{\text {th }} \mathrm{c}\right.$. village in Hungary. In: D. Campana., P. Crabtree., S.D. de France., J. Lev-Tov and A. Choyke (eds). Anthropological Approaches to Zooarchaeology. Colonialism, Complexity and Animal Transformations. Oxford: Oxbow Books, pp. 244-249.

Daróczi-Szabó M. 2014. Animal remains from the mid 12th-13th century (Árpád Period) village of Kána, Hungary. Dissertationes Archaeologicae 3(2): 541-548.

Deane J.K. 2013. medieval Domestic Devotion. History Compass 11(1): 65-76.

De Clercq W. 2009. Lokale gemeenschappen in het Imperium Romanum. Transformaties in rurale bewoningsstructuur en materiële cultuur in de landschappen van het noordelijk deel van de civitas Menapiorum (Provincie Gallia-Belgica, ca. 100 v.Chr. 400 n.Chr.). Unpublished thesis, University of Gent.

Dieleman K. 2012. Religious Imaginaries: The Liturgical and Poetic Practices of Elizabeth Barrett Browning, Christina Rossetti, and Adelaide Procter. Ohio: Ohio University Press.

Duffin C.J. 2007. Alectorius: The Cock's Stone. Folklore 118(3): 325-341. 


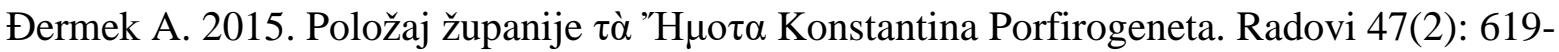
640

Džino D. 2010. Becoming Slav, Becoming Croat: Identity Transformations in Post-Roman and Early medieval Dalmatia. Leiden, Boston: BRILL.

Džino D. 2014a. Local knowledge and wider contexts: stories of the arrival of the Croats in De Administrando Imperio in the past and present. In: D. Džino and K. Parry (eds). Byzantium, its neighbors and its cultures. Byzantina Australiensia 20. Brisbane: Australian Association for Byzantine Studies, pp. 89-105.

Džino D. 2014b. The rise and fall of the Dalmatian 'Big-men': Social structures in Late Antique, Post-Roman and Early medieval Dalmatia (ca. 500-850). Studia Academica Šumenensia 1: 127-152.

Džino D. 2017/2018. Starokršćanski bazilikalni kompleks i grobovi u tumulima u Ljubaču: Odgonetanje „mračnog“ doba Dalmacije. Starohrvatska prosvjeta 3(44-45): 89-113.

Džino D. 2018. Post-Roman Dalmatia: collapse and regeneration of a complex social system. In: M. Ančić., J. Shepard and T. Vedriš (eds). Imperial spheres and the Adriatic: Byzantium, the Carolingians and the Treaty of Aachen (812). London: Routledge, pp. 155-173.

Feider M.P. 2017. Chickens in the Archaeological Material Culture of Roman Britain, France, and Belgium. Unpublished PhD, Bournemouth University.

Filipec K. 2009. A Slavic Cremation Grave from Lobor. Archaeologia Adriatica 3(1): 347357.

Fogelin L. 2007. The Archaeology of Religious Ritual. Annu. Rev. Anthropol. 36:55-71

Gaonkar D.P. 2002. Toward new imaginaries: An introduction. Public Culture 14(1): 1-19.

Gazin-Schwartz A. 2001. Archaeology and folklore of ritual, material culture, and everyday life. International Journal of Historical Archaeology 5(4): 263-280.

Gerritsen F. 1999. To build and to abandon. The cultural biography of late prehsitorichouses and farmsteads in the southern Netherlands. Archaeol. Dial. 2: 78-97.

http://dx.doi.org/10.1017/S1380203800001410

Ghica V., Milošević A., Uroda N and Dzino D. 2017. Varvaria / Breberium / Bribir

Archaeological Project: the 2015 excavation season. Hortus Artium Mediaevalium 23(2): 776-796.

Gilchrist R. 2008. Magic for the Dead? The Archaeology of Magic in Later medieval Burials. medieval Archaeology 52(1): 119-158. http://dx.doi.org/10.1179/174581708x335468

Gilchrist R. 2012. medieval Life. Archaeology and the Life Course. Woodbridge: Boydell Press.

Gjurašin H. 2000. Šuplja crkva u Solinu. Arheološka istraživanja 1998. i 2001. Godine. Starohrvatska prosvjeta (3)27: 83-87.

Goldstein I. 1999. Between Byzantium, the Adriatic and Central Europe. In: I. Supičić (ed). Croatia in the Early Middle Ages. London: Philip Wilson Publishers, pp. 169-180.

Grau-Sologestoa I. 2018. Pots, chicken and building deposits: The archaeology of folk and official religion during the High Middle Ages in the Basque Country. Journal of Anthropological Archaeology 49: 8-18. 
Green N. 2006. Ostrich Eggs and Peacock Feathers: Sacred Objects as Cultural Exchange between Christianity and Islam. Al-Masāq 18(1): 27-78.

Hamerow H. 2006. Special deposits in anglo-saxon settlements. medieval Archaeol. 50: 130. http://dx.doi.org/10.1179/174581706x124211

Hansen S.C.J. 2009. Whetstones from Viking Age Iceland: As Part of the TransAtlantic Trade in Basic Commodities. Unpublished MA thesis, University of Iceland.

Hansson A-M. 2005. Buried plants: Fossil plant remains from two Early medieval burial mounds in east-central Sweden. Journal of Nordic Archaeological Science 15: 39-56.

Hendel R.S. 2009. Sacrifice as a Cultural System: The Ritual Symbolism of Exodus 24,3-8. Zeitschrift für die alttestamentliche Wissenschaft 101(3): 366-390.

Herva V-P. 2009. Living (with) Things: Relational Ontology and Material Culture in Early Modern Northern Finland. Cambridge Archaeological Journal 19(3): 388-397.

Herva V-P. 2010. Buildings as persons: Relationality and the life of buildings in a northern periphery of early modern Sweden. Antiquity 84(324): 440-452.

Herva V-P. 2012. Spirituality and the material world in post-medieval Europe. In: K. Rountree., C. Morris and A.A.D. Peatfield (eds). Archaeology of Spiritualities. London: Springer, pp. 71-26.

Herva V-P. and Ylimaunu T. 2009. Folk beliefs, special deposits, and engagement with the environment in early modern northern Finland. Journal of Anthropological Archaeology 28: 234-243.

Hukantaival S. 2007. Hare's feet under a hearth - discussing 'ritual' deposits in buildings. In: V. Immonen., M. Lempiäinen and U. Rosendahl (eds) Hortus novus: Fresh Approaches to medieval Archaeology in Finland. The Society for medieval Archaeology in Finland 14. Turku : Suomen keskiajan arkeologian seura, pp. 66-75.

Hukantaival S. 2013. Finding Folk Religion. An Archaeology of 'Strange' Behaviour. Folklore: Electronic Journal of Folklore 55: 99-124.

Hukantaival S. 2016. For a witch cannot cross such a threshold!. Building concealment traditions in Finland c.1200-1950. The Society for medieval Archaeology in Finland 23. Turku: Suomen keskiajan arkeologian seura.

Hutton R (ed). 2016. Physical Evidence for Ritual Acts, Sorcery and Witchcraft in Christian Britain: A Feeling for Magic. Basingstoke: Palgrave Macmillan.

Insoll T. (ed). 2001. Archaeology and World Religion. London: Routledge.

Insoll T. (ed). 2004. Archaeology, Ritual, Religion. London: Routledge.

Insoll T. (ed). 2011. The Oxford Handbook of the Archaeology of Ritual and Religion. Oxford: Oxford University Press.

Ivancu E., Klimkowski T. 2016. From Jericho to Argeș, Deva, Dynas Emrys, and Surami: the myth of construction between curse and sacrifice. Acta Philologica 49: 53-68.

Johanson K. 2009. The Changing Meaning of 'Thunderbolts'. Folklore 42: 129-174.

Jonuks T., Oras E., Best J., Demarchi B., Mänd R., Presslee S., Vahur S. 2018. Multi-method Analysis of Avian Eggs as Grave Goods: Revealing Symbolism in Conversion Period Burials at Kukruse, NE Estonia. Environmental Archaeology 23(2): 109-122. 
Karbić D. 2005. The Šbići of Bribir glavica until the Loss of the Hereditary Position of the Croatian Ban (1322). Papers and Proceedings of the Department of Historical Research of the Institute of Historical and Social Research of Croatian Academy of Sciences and Arts 22:126.

King A. 2005. Animal remains from temples in Roman Britain. Britannia 36: 329-69.

Kraidy M. 2005. Hybridity, or the cultural logic of globalization. Philadelphia, PA: Temple University Press.

Kynes S. 2017. Plant Magic: A Year of Green Wisdom for Pagans \& Wiccans. Wales: Llewellyn Publications.

Lents H. 2016. Swinging Censers: the Late Antique Christian Transition to Incense Use in the Fourth to Sixth Centuries CE. Unpublished MA thesis, Brandeis University.

Lodwick L. 2015. Identifying Ritual Deposition of Plant Remains: A Case Study of Stone Pine Cones in Roman Britain. In: T. Brindle., M. Allen., E. Durham and A. Smith (eds). TRAC 2014: Proceedings of the Twenty Fourth Annual Theoretical Roman Archaeology Conference. Oxford: Oxbow, pp.54-69.

Loog L., Thomas M.G., Barnett R., Allen R., Sykes N., Paxinos P.D., Lebrasseur O., Dobney K., Peters J., Manica A., Larson G., Eriksson A. 2017. Inferring Allele Frequency Trajectories from Ancient DNA Indicates That Selection on a Chicken Gene Coincided with Changes in medieval Husbandry Practices. Molecular Biology and Evolution 34(8): 19811990.

Majnarić I. 2018. In the shadows of empires: Early medieval Croatia in the ninth and tenth centuries. History compass 16(7): e12462. https://doi.org/10.1111/hic3.12462

Manning C.M. 2014a. Magic, Religion, and Ritual in Historical Archaeology. Historical Archaeology 48(3): 1-9.

Manning C.M. 2014b. The Material Culture of Ritual Concealments in the United States. Historical Archaeology 48(3): 52-83.

Markotić V. 1964. Historical Archaeology. In: F.H. Eterovich and C. Spalatin (eds). Croatia: Land, People, Culture. Volume 1. Canada: University of Toronto.

Martens M. 2004. Re-thinking sacred "rubbish": The ritual deposits of the temple of Mithras at Tienen (Belgium). Journal of Roman Archaeology 17: 333-353.

Merrifield R. 1987. The Archaeology of Ritual and Magic. London: New Amsterdam Books Mitchell S.A. 1985. The Whetstone as symbol of authority in Old English and Old Norse. Scandinavian Studies 57(1): 1-31.

Milošević A. 2015. Primjer ritualne žrtve pri gradnji kuće na srednjovjekovnom Bribir glavicau. Starohrvatska prosvjeta 42:45-58.

Milošević A. 2017. The Early medieval Stirrup from Bribir glavica. Hortus Artium medievalium 2(23): 750-760.

Mirnik I. 2005. Coins from early Croatian graves. Vjesnik Arheološkog muzeja u Zagrebu 37(1): 205-250.

Mirnik I. 2007. Coins from Bribir glavica (Varvaria). Slovenská numizmatika XVIII: 157180. 
Musty J. 1969. The Excavation of Two Barrows, One of Saxon Date, at Ford, Laverstock, near Salisbury, Wiltshire. The Antiquaries Journal 49(1): 98-117.

Newall V. 1968. Easter Eggs. Folklore 79(4): 257-278.

O'Connor L. 1991. Irish Iron Age and Early Christian Whetstones. The Journal of the Royal Society of Antiquaries of Ireland 121: 45-76.

Osborne R. 2004. Hoards, Votives, Offerings: The Archaeology of the Dedicated Object. World Archaeology 36(1): 1-10.

Papeša A.R., Kenéz Á., Pető Á. 2015. The Archaeobotanical Assessment of Grave Samples from the Avar Age Cemetery of Nuštar (Eastern Croatia). Prilozi Instituta za arheologiju u Zagrebu 32(1): 261-288.

Papy J. 2000. In praise of the omnipresent egg: Erycius Puteanus' Ovi Encomium (1615). Humanistica Lovaniensia XLIX: 317-38.

Paulsson-Holmberg T. 1997. Iron Age building offerings: a contribution to the analysis of a die-hard phenomenon in Swedish preindustrial agrarian society. Fornvännen 92(3/4): 163175 .

Pelling R., Campbell G., Carruthers W., Hunter K., Marshall P. 2015. Exploring Contamination (Intrusion and Residuality) in the Archaeobotanical Record: Case Studies from Central and Southern England. Vegetation History and Archaeobotany 24(1): 85-99.

Petaros A., Skrobonja A., Culina T., Bosnar A., Frkovic V., Azman J. 2013. Public Health Problems in the medieval Statutes of Croatian Adriatic Coastal Towns: From Public Morality to Public Health. Journal of Religious Health 52: 531-537.

Petrinec M. 2010. Metal Objects of Byzantine Origin in medieval Graves from Croatia. In: P L. Grotowski and S. Skrzyniarz (eds). Towards rewriting? New approaches to Byzantine Archaeology and Art. Warsaw, Polish Society of Oriental Art: Cardinal Stefan Wyszyński University, pp. 197-212.

Petrinec M. 2012. Croatia between the east and the west - evidence from early medieval graves. In: M. Salamon., M. Wołoszyn., A. Musin and P. Špehar (eds). Rome, Constantinople and Newly-Converted Europe: Archaeological and Historical Evidence. Volume 1. Kraków, Instytut Archeologii Uniwersytetu Rzeszowskiego, pp. 461-474.

Petrinec M. 2015. Frühmittelalterliche Gräber aus Orlić Angesichts Bisheriger Erkenntnisse über den Horizont mit Heidnischen Bestattungsmerkmalen. Starohrvatska prosvjeta 42: 81131.

Pieta K., Robak Z. 2012. Early medieval Barrows in Bojná.

http://www.mocenskecentra.sav.sk/publikacie.php [accessed 07/12/2018]

Rappaport R.A. 1999. Ritual and Religion in the Making of Humanity. Cambridge: Cambridge University Press.

Raukar T. 1999. Land and Society. In: I. Supičić (ed). Croatia in the Early Middle Ages. London: Philip Wilson Publishers, pp. 181-196.

Reed K. 2016. Archaeobotany in Croatia: An overview. Journal of the Archaeological Museum in Zagreb 49(1): 7-28

Reed K., Lodwick L., Leleković T., Vulić H. 2019. Exploring Roman ritual behaviours through plant remains from Pannonia Inferior. Environmental Archaeology 24(1): 28-37. 
Reniere S., De Clercq W. 2018. Gallo-Roman whetstone building deposits. The cultural biography of the domestic sphere in northern Gaul. Journal of Anthropological Archaeology 51: 67-76.

Robinson M. 2002. Domestic Burnt Offerings and Sacrifices at Roman and pre-Roman Pompeii, Italy. Vegetation History and Archaeobotany 11: 93-100.

Rovira N., Chabal L. 2008. A foundation offering at the Roman port of Lattara (Lattes, France): the plant remains. Vegetation History and Archaeobotany 17(Suppl 1): S191-S200.

Saunders C. 2010. Magic and the Supernatural in medieval English Romance. Cambridge: D.S. Brewer.

Schott R.M. 2010. Sexual Violence, Sacrifice, and Narratives of Political Origins. In: R.M. Schott (ed). Birth, Death, and Femininity: Philosophies of Embodiment. Indiana: Indiana University Press, pp.25-48.

Šeparović T. 2009. Skupni nalaz novca iz 5. i 6. stoljeća na lokalitetu Klapavice - Crkvina kod Klisa. Starohrvatska Prosvjeta 3(36): 27-34.

Šeparović T. 2011. Skupni nalaz novca četrnaestog stoljeća s Bribirske glavice. Starohrvatska Prosvjeta 3(39): 215-230.

Sheppard H.J. 1958. Egg Symbolism in Alchemy. Ambix 6(3): 140-148.

Simpson J. 1979. The King's whetstone. Antiquity 53(208): 96-101.

Slaveykov R. 2014. Bulgarian folk traditions and beliefs. Sofia: Asenevtsi.

Smith J.B. 2003. Lying for the Whetstone: A Saying and its Links with Folk Life and Tradition. Folk Life 42(1): 54-60.

Smičiklas T (ed). 1905. Codex Diplomaticus Regni Croatiae, Dalmatiae, et Slavoniae III, 316. Zagreb: Ex Officina Societatis Typographicae.

Sokol V. 2015. medieval Jewelry and Burial Assemblages in Croatia: A study of graves and grave goods, ca. 800 to ca. 1450. Beaverton: Ringgold.

Stevenson A (ed). 2010. The Oxford Dictionary of English, 3rd edition. Oxford: Oxford University Press.

Sykes N. 2012. A social perspective on the introduction of exotic animals: the case of the chicken. World Archaeology 44(1): 158-169.

Taylor C. 2004. Modern Social Imaginaries. Durham: Duke University Press.

Thomas G., Pluskowski A., Gilchrist R., Ruiz G.G-C., Andrén A., Augenti A., Astill G., Staecker J., Valk H. 2017. Religious transformations in the Middle Ages: towards a new archaeological agenda. medieval Archaeology 61(2): 300-329.

Van der Veen M. 2007. Formation processes of desiccated and carbonized plant remains - the identification of routine practice. Journal of Archaeological Science 34(6): 968-990.

Vedriš T. 2009. "'Frankish" or "Byzantine" saint? The origins of the cult of St. Martin in Dalmatia', in: Papers from the First and Second Postgraduate Forums in Byzantine Studies / Savvas Neocleous (ur.). Cambridge: Cambridge Scholars Publishing, pp. 221-249.

Vedriš T. 2015. Crkva i vjerski život. In: Z. Nikolić Jakus (ed). Nova zraka u europskom svjetlu: Hrvatske zemlje u ranome srednjem vijeku (oko 550-oko 1150). Zagreb: Matica hrvatska, pp. 201- 235. 
Versnel H.S. Some Reflections on the Relationship Magic-Religion. Numen 38(2): 177-197.

Watkins C. 2004. "Folklore" and "popular religion" in Britain during the middle ages.

Folklore 115(2): 140-150.

Watkins F., Pendry B., Sanchez-Medina A., Corcoran O. 2012. Antimicrobial assays of three native British plants used in Anglo-Saxon medicine for wound healing formulations in 10th century England. Journal of Ethnopharmacology 144(2): 408-415.

Watson G., Gilchrist R. in press. Objects: the Archaeology of medieval Healing. In: I. McCleery (ed). The Cultural History of Medicine in the Middle Ages. London: Bloomsbury.

Wenska I. 2015. Sacrifices among the Slavs: Between archeological evidence and 19th century folklore. Analecta Archaeologica Ressoviensia 10: 271-311.

Winter C. 2012. Prisons and Punishments in Late medieval London. Unpublished PhD thesis, University of London.

Woodward P., Woodward A. 2004. Dedicating the town: urban foundation deposits in Roman Britain. World Archaeology 36(1): 68-86. 